\title{
Possible natural fluid pathways from gravity pseudo-tomography in the geothermal fields of Northern Alsace (Upper Rhine Graben)
}

\author{
Paul Baillieux ${ }^{1 *}$, Eva Schill ${ }^{2}$, Yassine Abdelfettah ${ }^{1,2}$ and Chrystel Dezayes ${ }^{3}$
}

\author{
* Correspondence: \\ paul.baillieux@unine.ch \\ ${ }^{1}$ Centre for Hydrogeology and \\ Geothermics, Neuchâtel University, \\ rue Emile Argand 11, Neuchâtel \\ $\mathrm{CH}-2000$, Switzerland \\ Full list of author information is \\ available at the end of the article
}

\begin{abstract}
Background: This study aims on investigating the regional flow field of the Soultz and adjacent geothermal fields located on the western side of the central Upper Rhine Graben and thus to provide insight into the origin of the $70 \%$ of the geothermal fluid coming from the regional inflow in the deep reservoir of the Soultz site. In an integrative approach, we consolidate conceptual models on fluid flow in the central Upper Rhine Graben.

Methods: Based on a 3D geological model and a new 3D temperature interpolation, we tackle the relation between tectonic structures and the occurrence of advection/ convection along favourably oriented fault zones. Using sequential Butterworth filters, we study the distribution of negative residual anomalies in a pseudo-tomography down to a depth of about 6 to $8 \mathrm{~km}$.

Results: We derived N-S-striking V-shaped negative anomalies that are consistent with the orientation of fault zones revealing major temperature anomalies to their east.

Conclusions: Following the concept of negative anomalies revealing zones of increased fracture porosity, and in agreement with fluid-chemistry, our findings suggest infiltration of meteoric water through the graben boundary fault and along preferential flow pathways that merge at intermediate depth. Up-flow of thermal water mixed most likely with brine from the deeper eastern part of the graben occurs along W-dipping typically rather steep structures.
\end{abstract}


(1) Fluid-chemical analyses reveal equilibrium condition with a sedimentary environment of high salinity at temperatures around $250^{\circ} \mathrm{C}$ (Aquilina et al. 1997; Sanjuan et al. 2010). Geologically, such condition is observed on the eastern side of the URG, only.

(2) Fluid inclusions suggest a more local circulation involving down-flow of cold fluid with sedimentary signature and up-flow from $>5-\mathrm{km}$ depth of high temperature and low salinity fluids probably of meteoric origin and most likely from the adjacent Vosges Mountains (Cathelineau and Boiron 2010; Dubois et al. 2000; Dubois et al. 1996).

Accordingly, in the western part of the URG, a fault-related discharge zone for the basin-wide circulation system was assumed to account for about $50 \%$ increase of the mean heat flux of about $80 \pm 10 \mathrm{~mW} \mathrm{~m}^{-2}$ at the top crystalline basement (Clauser and Villinger 1990).

The aim of this study is to investigate the possible pathways for fluid inflow into the Soultz and adjacent geothermal fields (e.g. the Rittershoffen field). On a graben-wide scale, Illies and Greiner (1979) stated that convective heat transport occurs along N-S-striking fracture zones, because they are favourably oriented with respect to the present-day stress field to be reactivated. On a local scale, Bächler et al. (2003) have shown that these graben-parallel faults are capable of hosting hydrothermal convection organized into cells. Additionally, on intermediate scale between Speyer and Soultz, Schill et al. (2009) pointed out that major thermal anomalies are related to horst structures. Internally in the Soultz horst, an electrical conductivity anomaly indicating hydrothermal circulation is observed at the western horst boundary fault, only (Geiermann and Schill 2010). Thus, it may be concluded that only part of the faults is capable of hosting fluid circulation.

Here, we present the re-evaluation of gravity and magnetic data in terms of properties of geological structures. To this end, a new 3D geological model of the Soultz area had been established (Baillieux et al. 2011) based on the re-interpretation of seismic lines (Dezayes et al. 2011). In this study, temperature anomalies were re-located using 3D interpolation and compared to the structural pattern of the 3D geological model. After reprocessing and reinterpretation of gravity and magnetic data and application of pseudotomography, these results were compared to temperature distribution and analysed for possible fracture porosity.

\section{Geological setting}

The interpretation of geophysical data in terms of basement structures and hydraulic properties requires a sound knowledge on possible lithological changes (Abdelfettah et al. 2014; Denlinger and Kovach 1981). In this respect, in the geological setting, we will focus on both the basement lithology and the structural setting of the area of investigation.

The Variscan crystalline basement of the URG (Figure 1) is characterized by important lithological changes that are mainly organised in a succession of NE-SW-trending and SE-dipping subduction and underthrusting zones representing from north to south, the Rhenohercynian, the Saxothuringian and the Moldanubian terranes. Geophysically, they are represented by gravity and magnetic anomalies (Figure 1) as well as SE-dipping, deep seismic reflectors (Brun et al. 1992). The northern Saxothuringian zone is mainly composed of Precambrian gneisses and schists crossed by the 335- to 330-Ma calcalkaline plutonism composed of diorites, granodiorites and granites, whereas the southern 


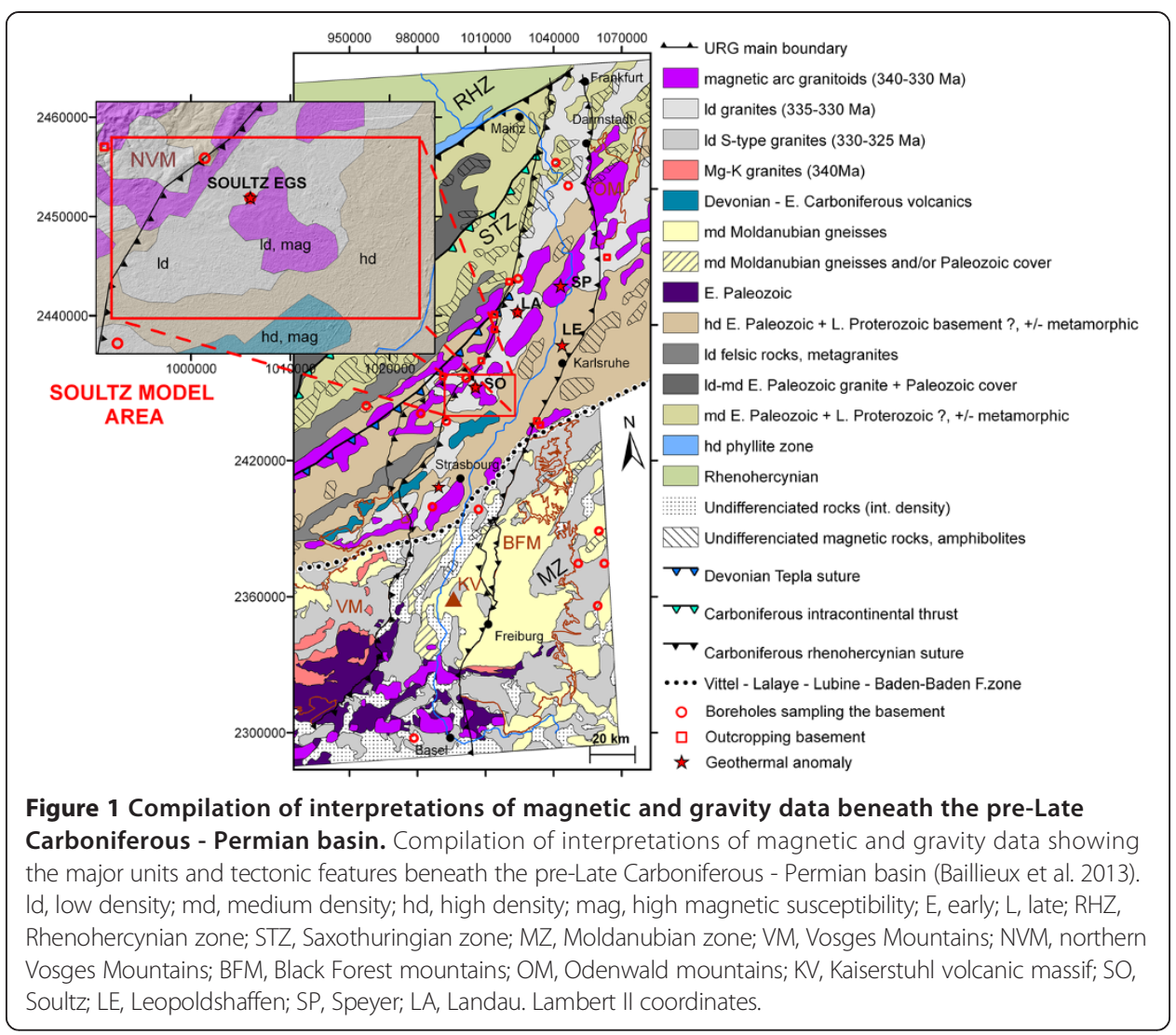

Moldanubian zone is dominated by high-pressure metamorphism, by syenitic magmatism (340 Ma) and followed by crustal origin magmatism (330 to $325 \mathrm{Ma}$ ) (Altherr et al. 2000; Boutin et al. 1995; Edel 2004; Edel et al. 1986). In the centre of the Saxothuringian zone, a previous subduction system is supposed from by volcanic formations of Devonian age. The Soultz EGS site is located at the rim of a magnetic zone of the Saxothuringian terrane (Figure 1, inlet).

The late phase of the Variscan orogeny is characterized by large-scale extension causing mainly NNE-SSW-trending graben structures such as the Kraichgau or Schramberg troughs (Ziegler et al. 2004). The eroded massif provides depositional environment to Mesozoic platform sediments of Triassic (Buntsandstein, Muschelkalk and Keuper) and Jurassic (Lias and Dogger) times. The URG originates in Paleogene times from the Alpine collision due to the build-up of far-field intraplate compressional stresses (Ziegler 1992) and is described as a typical example of syn-orogenic, intra-continental foreland rifting affected by Variscan crustal pre-discontinuities (Cloetingh et al. 2006; Dèzes et al. 2004; cf. discussions on the topic in Schumacher 2002).

\section{D structural model of the Soultz area}

In the following, we will shortly describe the geological model (Baillieux et al. 2011; Dezayes et al. 2011). The 3D structural model of $31 \times 18.5 \times 6 \mathrm{~km}$ around the Soultz EGS site incorporates a network of 26 faults. Often, strike-slip features such as negative flower structures are present as well (Beccaletto et al. 2010). The horst structure 
beneath the Soultz site is indicated in 3D geological models. Most of the major normal faults cross-cut the Cenozoic and Mesozoic sediments into the top of the crystalline basement, but can hardly be traced further in its deep part. For the geological model, those faults have been extrapolated down to the main boundary fault or the bottom of the model at $-6,000 \mathrm{~m}$ below sea level. The orientation of the major faults is NNESSW. Inside the different tectonic units, secondary faults trend NNW-SSE to N-S predominantly dipping to the west. It should be mentioned that there is a remarkable correlation between the orientation of secondary faults obtained from triangulated fault surfaces and fracture orientation, the reservoir (Baillieux et al. 2011). This suggests at least partial coupling of deformation between the sedimentary overburden and the basement at Soultz. Additionally, most of these fractures are water-bearing prior to stimulation and form the main flow channels after stimulation and during circulation (Dezayes et al. 2010 and references therein). The orientation of these fractures is consistent with the present-day stress field, for which measured and derived orientations of $\mathrm{S}_{\mathrm{Hmax}}$ determined down to $5,000 \mathrm{~m}$ vary between $\mathrm{N} 125^{\circ} \mathrm{E}$ and $\mathrm{N} 185^{\circ} \mathrm{E}$ with a mean value of $\mathrm{N} 175^{\circ} \mathrm{E} \pm 10^{\circ}$ (Cornet et al. 2007; Klee and Rummel 1993; Valley and Evans 2010).

\section{Methods}

\section{Temperature interpolation}

A detailed review on the data, its quality and the interpolation method are provided (Baillieux et al. 2013). A number of 112 wells with temperature measurements were available from the existing LIAG database (Agemar et al. 2012). They are classified according to their quality in categories $\mathrm{A}$ to $\mathrm{C}$ indicating undisturbed data (category A), disturbed logs or from bottom hole temperature (BHT) measurements (category B) and BHT with insufficient further information (category C). The distribution and quality of the data used in this study is provided in Figure 2. It becomes evident that category A data are unevenly distributed and are mainly available around the Soultz EGS site as well as towards the southeast of the area of investigation. In the northeastern part, there are few category $\mathrm{B}$ and a large number of category $\mathrm{C}$ data. For this reason, data in the northeastern corner have been completed by a number of measurements outside the original study area. It should be mentioned that in the original data, temperature values are indicated with an error of up to $\pm 8^{\circ} \mathrm{C}$ to $10^{\circ} \mathrm{C}$ depending on the depth range (Agemar et al. 2012 and references therein). For example, at a depth of 2,000 m, measurements from categories $\mathrm{B}$ and $\mathrm{C}$ tend to underestimate the formation temperature by around $4^{\circ} \mathrm{C}$ to $6^{\circ} \mathrm{C}$ in the given database.

For interpolation, we have chosen 3D Delaunay triangulation since the variograms of multi-Gaussian kriging reveals only limited fit with the Gaussian function (Agemar et al. 2012) and thus, maintaining the exact temperature value for known locations is in favour of this kind of interpolation. Following triangulation, we have applied natural neighbour interpolation on a grid with $250-\mathrm{m}$ sampling size in the $\mathrm{X}$ (easting) and $\mathrm{Y}$ (northing) directions and $100 \mathrm{~m}$ in the $\mathrm{Z}$ (depth) direction. This volumetric data is sliced at different depths using a tri-linear interpolation and represented at top basement. Finally, the minimum geothermal gradient is selected and subtracted from the absolute temperature values in order to highlight local 


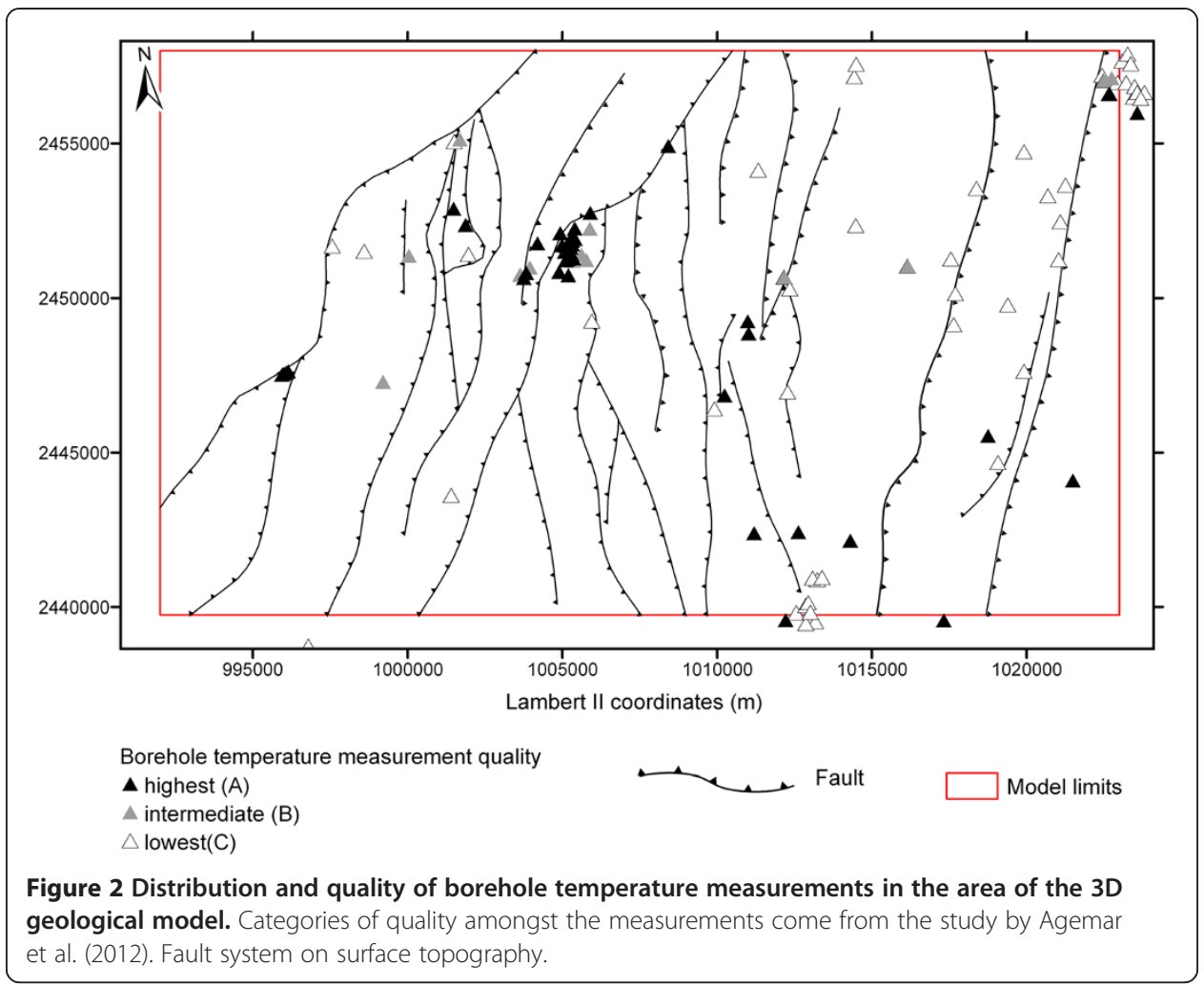

effects. The resulting corrected temperature anomaly (or CTA) is calculated using the following formula:

$$
\operatorname{CTA}(X, Y, Z)=T(X, Y, Z)-\frac{\Delta T}{\Delta Z} Z
$$

where $\mathrm{T}$ is temperature and $\mathrm{Z}$ the depth below sea-level, and $\Delta \mathrm{T} / \Delta \mathrm{Z}$ is the minimum observed geothermal gradient.

\section{Geophysical data processing}

Apart from the interpreted seismic lines incorporated into the 3D geological model, in this study, we have investigated existing magnetic and gravity data for physical properties of the seismically identified fault zones. Therefore, existing data were analysed with reference to the local structural setting. In the area of investigation, a number of 837 homogenously distributed, ground magnetic data (Edel et al. 1982; Papillon 1995) were reduced to pole. Gravity data were taken from (Rotstein et al. 2006) database. To avoid physical inconsistency in the gravity data, redundant datasets with offsets were removed and a total of 1,011 measurements were selected. The dataset provides a complete Bouguer anomaly with a reference density of $2,670 \mathrm{~kg} \mathrm{~m}^{-3}$ and a terrain correction using a digital elevation model with a grid spacing of $75 \mathrm{~m}$, to a maximum radius of $22 \mathrm{~km}$.

In order to investigate the contribution of structures at different depth to the Bouguer anomaly, a pseudo-tomography has been obtained using a number of low-pass Butterworth filter wavelengths between 20 and $150 \mathrm{~km}$ (Butterworth 1930), on an extended area of investigation of $150 \times 150 \mathrm{~km}$ using the entire graben gravity database outside (Rotstein et al. 2006) and the selected data inside the area of investigation. The presented study area 
is centred in the extended area. A detailed sensitivity study on the potential of preferential filtering is presented (Abdelfettah et al. 2014). Gravity forward modelling was carried out using Pohanka's algorithm (Pohanka 1988) applied to a finite element model. The applied densities are obtained by comparing measurements in Soultz boreholes (Genter 1990; Grecksch et al. 2003; Rummel and König 1991) with average regional densities (Campos-Enriquez et al. 1992; Edel and Weber 1995; Papillon 1995; Rotstein et al. 2006) and listed in Table 1.

\section{Results and discussion}

In the following, we are discussing the distribution of thermal anomalies with respect to structural and mechanical aspects. The geophysical results are discussed with respect to the observed link between thermal, magnetic and gravity anomalies on a graben-wide scale (Baillieux et al. 2013).

\section{Temperature distribution at top basement}

Before analysing the temperature data, we have determined overall maximum and minimum linear temperature gradients of $>110$ and $39.2^{\circ} \mathrm{C} \mathrm{km}^{-1}$ that envelops all temperature measurements from the 112 available boreholes. The comparatively high upper limit represents the conduction in the sedimentary layer above convection cells (Kohl et al. 2000), whereas the lower limit indicates temperature increase with depth originating from heat conduction from the underlying part of the respective depth, only. In order to highlight the temperature anomalies, the latter is subtracted from the resulting temperature interpolation. In the following, we refer to this as corrected temperature anomaly (CTA). In agreement with earlier regional studies, the original interpolation shows a general trend of increasing temperature with depth with major increase in the central part of the investigation area. The intersection of CTA with the eastward deepening top basement reveals a more detailed pattern of three temperature anomalies (Figure 3). The quality of the interpolation is indicated by the number of measurements in the basement or with different distances to it. Both anomalies at Soultz and Rittershoffen reach CTA values of $>85^{\circ} \mathrm{C}$ and are constrained by temperature logs into the basement (Agemar et al. 2012). The latter reference from Villadangos (pers. comm.) is not included in the database and thus, does not appear in Figure 3. The third anomaly close to Rohrlach is only little constrained by one measurement at approximately $500 \mathrm{~m}$ above the top basement.

Comparing the location of the thermal anomalies to the structural setting obtained from the 3D geological model, we find that all three anomalies are located directly east of N-S-striking and W-dipping faults that in the case of Soultz and Rittershoffen represents

Table 1 Densities used for the gravity forward modelling obtained by comparing measurements in Soultz boreholes (Genter 1990; Grecksch et al. 2003; Rummel and König 1991) with average regional densities (Campos-Enriquez et al. 1992; Edel and Weber 1995; Papillon 1995; Rotstein et al. 2006)

\begin{tabular}{lcc}
\hline Series & Constituting rocks & Density $^{\left(\mathbf{k g ~ m}^{\mathbf{- 3}} \mathbf{)}\right.}$ \\
\hline Tertiary & Limestone/marls/sandstone & 2,350 \\
Jurassic & Jurassic limestone/marls & 2,550 \\
Keuper & Marls/dolomite/limestone/sandstone & 2,700 \\
Muschelkalk & Marls/dolomite/sandstone/limestone & 2,700 \\
Buntsandstein & Sandstone/conglomerate & 2,500 \\
Basement & Porphyric monzogranite/two-mica granite & 2,600 \\
\hline
\end{tabular}




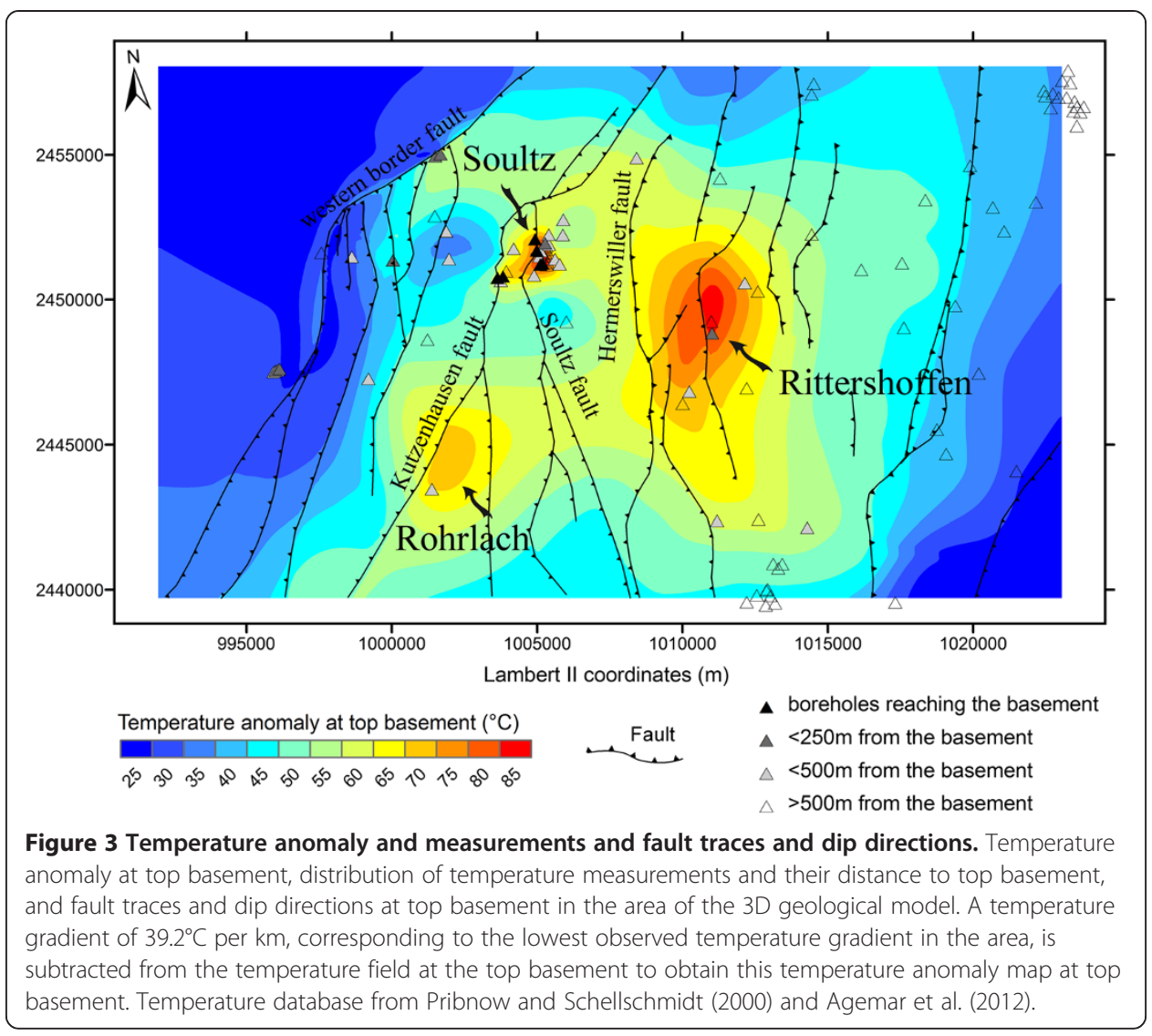

the western limit of a horst structure (Figure 3). Interestingly, the observation of a relation to horst structures holds also for the thermal anomalies of Landau, Speyer (Schill et al. 2009) and Leopoldshafen (Illies 1965). Further indication for the relation between west-dipping faults and thermal anomalies is provided by the analysis of fracture families in the deep part of the wells (4 to $5 \mathrm{~km}$ ) in Soultz, where the largest number of fractures with natural or enhanced transmissivity are dipping to the west (Baillieux et al. 2011; Dezayes et al. 2010; Sausse et al. 2010). As mentioned above, the main hydrothermal alteration interpreted from magnetotelluric data is observed across the W-dipping Soultz and Kutzenhausen faults (Geiermann and Schill 2010). Analysing fluid inclusions, Cathelineau and Boiron (2010) have found indication for a paleo circulation characterized by upward flow of thermal water with meteoric signature and interpreted this as deep circulation originating from the Vosges Mountains.

\section{Results from potential field methods}

Magnetic anomalies reduced to pole are presented and compared to the CTA from the top basement in Figure 4. The maximum CTAs of Soultz and Rittershoffen coincide with a positive magnetic anomaly of $>70 \mathrm{nT}$, whereas the little constrained CTA at Rohrlach is located at the rim of a negative anomaly with minima of $<-80 \mathrm{nT}$ and around -50 to $-40 \mathrm{nT}$ in the area of the thermal anomaly. A link between positive magnetic anomalies ranging in the order of few tens of $\mathrm{nT}$ and originating in Carboniferous gabbros, diorites and granodiorites (Figure 1) and their increased heat production rate contributing to the CTAs at Soultz and Rittershoffen has been discussed in an 


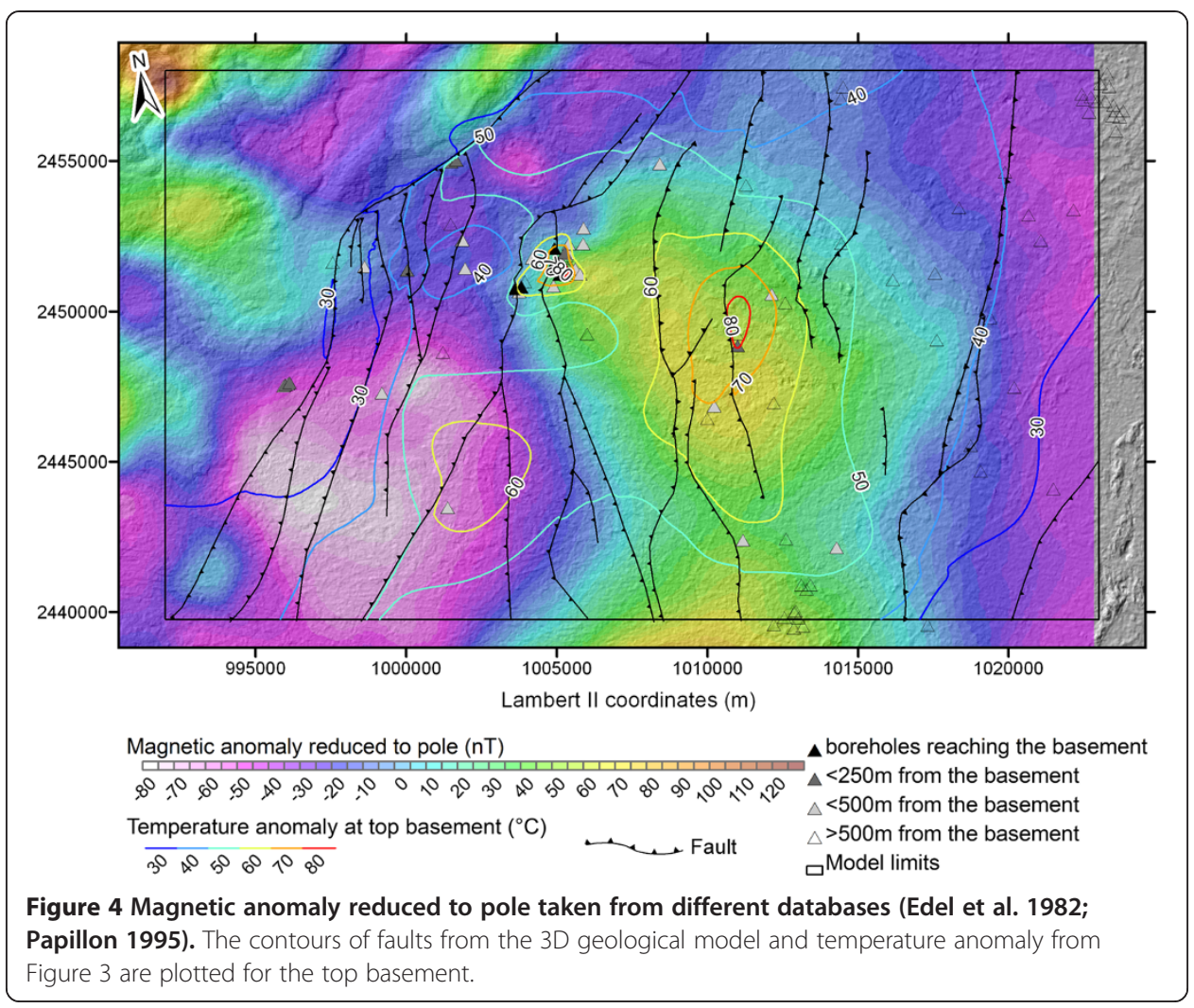

earlier study (Baillieux et al. 2013). A contribution of $15 \%$ to $25 \%$ of the temperature anomalies in the URG could be attributed to radiogenic heat production in this type of basement. This is consistent with the observed temperature.

The measured Bouguer anomaly is negative throughout the area of investigation and ranges between -39 and $-23 \mathrm{mgal}$ (Figure 5). Important negative anomalies are observed in the central part of the investigation area. In analogy to the regional observation revealing a general link between gravity lows $<-30 \mathrm{mgal}$ and positive temperature anomalies $>100^{\circ} \mathrm{C}$ at 2,000 m depth (Baillieux et al. 2013), we have compared our results to the CTAs.

It should be mentioned here that a direct correlation between the thickness of the Quaternary deposits (Bartz 1974) and negative gravity anomalies was not observed. Furthermore, Bouguer anomaly obtained from forward modelling (Baillieux et al. 2012) using a homogenous basement density reveals gradually decreasing gravity from about $-44 \mathrm{mgal}$ at the western boundary fault to about $-55 \mathrm{mgal}$ in the southeast of the study area (not shown). This is not compatible with the important negative anomalies observed in the centre of the investigation area. Stripping was carried out on the measured data based on the 3D geological model obtained from seismic data (Baillieux et al. 2012) to investigate the influence of the sedimentary cover on this prominent anomaly. No significant changes with respect to this anomaly were observed. This is in line with earlier results from gravity inversion that have shown that introducing a basement inhomogeneity of $250 \mathrm{~kg} \mathrm{~m}^{-3}$ density variation reduces the misfit between the forward modelled and the measured Bouguer anomaly (Schill et al. 2010). These findings confirm earlier interpretations of gravity in terms of 


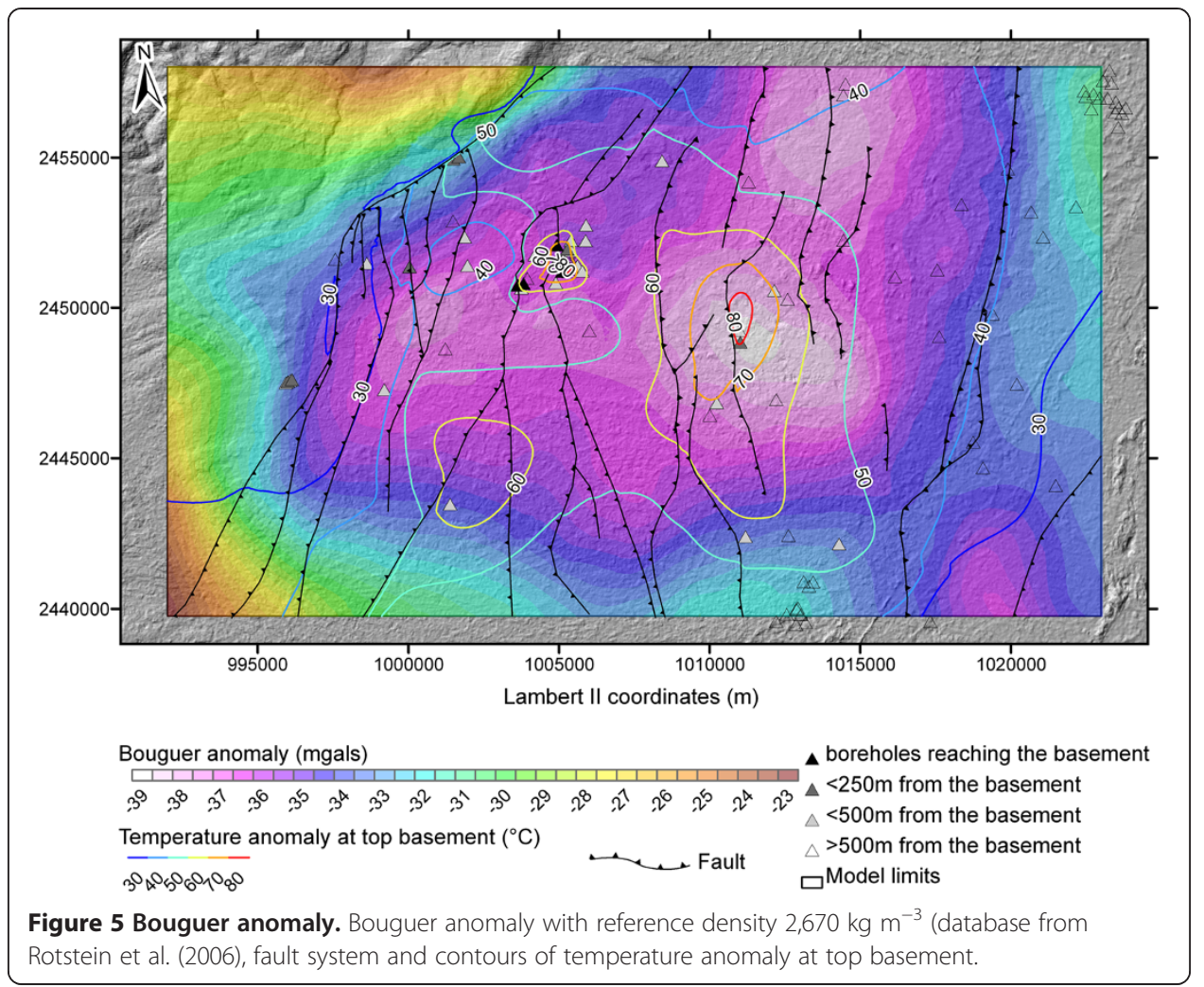

basement lithology (Rotstein et al. 2006). However, an alternative possibility may be variation in bulk density due to fracture porosity as suggested in other fractured reservoirs (Denlinger and Kovach 1981).

In this study, we focus on the evaluation of a series of Butterworth filters using variable wavelength in order to investigate the variation of density with depth in a pseudotomography. We have analysed Butterworth filtering using cut-off wavelengths between 20 and $120 \mathrm{~km}$, representing superficial and deep density variations, respectively (Figure 6).

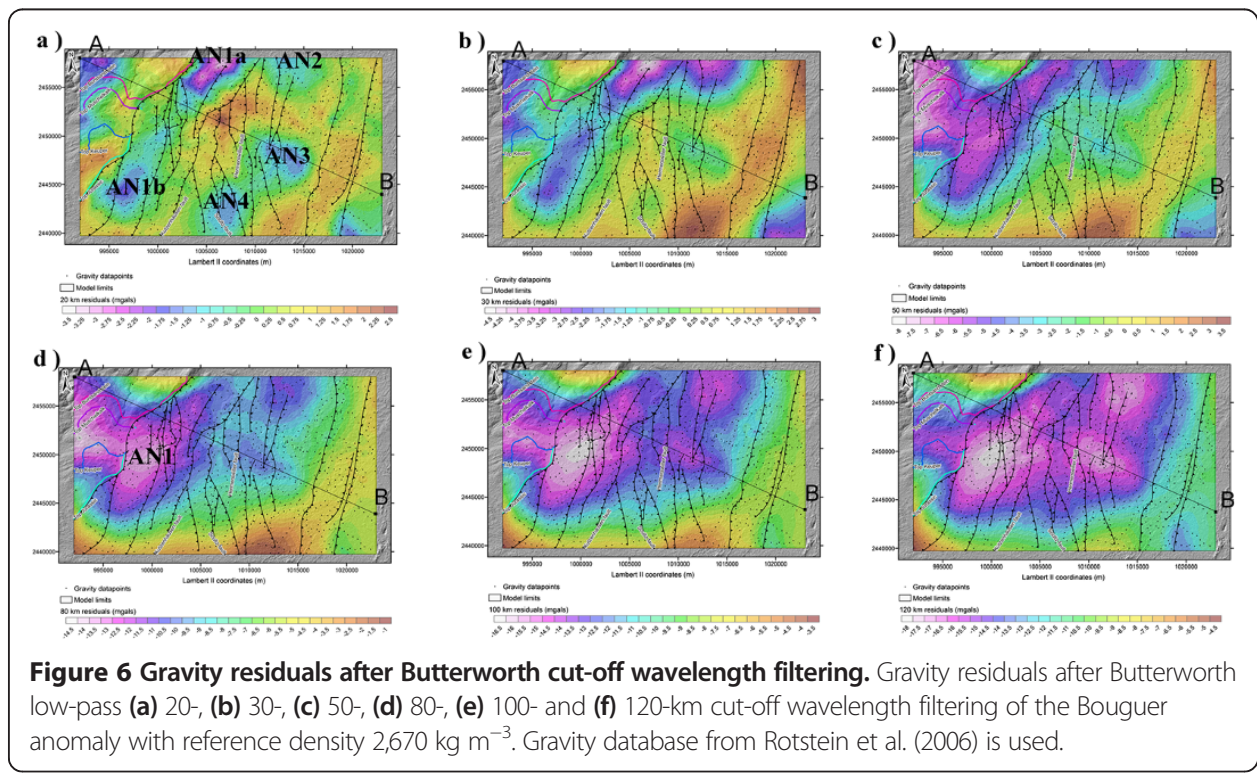


According to a recent sensitivity study in a similar geological environment (Abdelfettah et al. 2014), we may estimate the deep structures appearing at the applied longwavelength filters to be located in about 6 - to $8-\mathrm{km}$ depth; the 10 - to $20-\mathrm{km}$ filter typically indicates superficial often Quaternary deposits by negative anomalies. The negative residual anomalies with typical minima up to $-2 \mathrm{mgal}$ and locally up to $<-3.5 \mathrm{mgal}$ are located in the northwest, in the Buntsandstein formation of the Pfälzer Wald, directly to the east of the western Main Boundary fault (AN1a), to the east of the westernmost W-dipping fault (AN1b) within the URG and in the central part of the study area (AN2 to AN4; Figure 6a). The anomaly observed to the west of the Main Boundary fault becomes more prominent with increasing low cut-off wavelength $<80 \mathrm{~km}$ in terms of extension and gravity (up to $<-14.5 \mathrm{mgal}$ in the $80-\mathrm{km}$ filter, Figure $6 \mathrm{~b}-\mathrm{d}$ ). At wavelengths $>80 \mathrm{~km}$, no further variation is observed in this area (Figure 6e-f). More important variations in terms of gravity are observed within the URG. With increasing low cut-off wavelength, we observe the anomalies AN1a and AN1b to join at greater depth to AN1 $(\lambda>50 \mathrm{~km})$. This goes along with a decrease in minimum gravity from about $-4.5 \mathrm{mgal}$ in the $30-\mathrm{km}$ filter (AN1a) to $<-18 \mathrm{mgal}$ in the $120-\mathrm{km}$ filter (AN1) and an extension of the entire anomaly towards the east. The characteristics of the anomalies AN2 to AN4 develop differently. Anomaly AN2 shows continuous increase in extension developing towards the south with increasing low cut-off wavelength and increase in minimum gravity from about $-1.5 \mathrm{mgal}$ in the $20-\mathrm{km}$ filter to about $-17 \mathrm{mgal}$ in the $120-\mathrm{km}$ filter. In contrast, anomaly AN4 increases in gravity from about $-1.4 \mathrm{mgal}$ in the $20-\mathrm{km}$ filter to about $-0.5 \mathrm{mgal}$ in the 30-km filter (Figure 6a,b) and appears less prominent in the $>50-\mathrm{km}$ filters with respect to AN2 and AN3 (Figure 6c-f). It even disappears at depth. Finally, in the Bouguer anomaly, we observe that the anomalies AN2 and AN3 are the most important and it appears that AN1 and AN3 connect to each other at depth, i.e. AN1 extends towards east and AN3 towards west (Figure 5).

A final conclusion on the contribution of lithology and fracture porosity on gravity anomalies cannot be drawn from the potential field methods only. Taking the lithological observations in the 5,000 m wells at Soultz as a reference, we may develop a scenario for a strong lithological contribution. There is the positive magnetic anomaly coinciding with the AN1-AN3 gravity anomalies indicating a granitic intrusion of the so-called magnetite series (Ishihara 1977) with about $1 \mathrm{wt} . \%$ of primary magnetite as the main carrier of susceptibility (Just et al. 2004) and a mean density of about $2,660 \mathrm{~kg} \mathrm{~m}^{-3}$ (Rummel 1991). It may be speculated that the increasing extension of AN3 with increasing low cut-off wavelengths might be related to an increasing contribution of the underlying two-mica granite revealing typically lower susceptibility (Meller et al. 2014), but differences between the two in susceptibility are not very high (between about $1 \cdot 10^{-3}$ and $7 \cdot 10^{-3} \mathrm{~m}^{3} \mathrm{~kg}$ ). Density measurements in the two granites show that there is no significant change between them throughout the well lengths in Soultz (Grecksch et al. 2003). Cuttings from the geothermal well in Rittershoffen suggest that the petrography of the top crystalline in the centre of the anomaly is comparable to Soultz (Genter, pers. comm.).

There are two observations that assist the interpretation : (1) the geometry of the zones of low density in the sequential filters that is seen along W-E direction indicates a V-type structure joining at about 6- to 8- $\mathrm{km}$ depth following the orientation of major fault zones (Figures 6 and 7); and (2) the fact that no direct link between the magnetic 


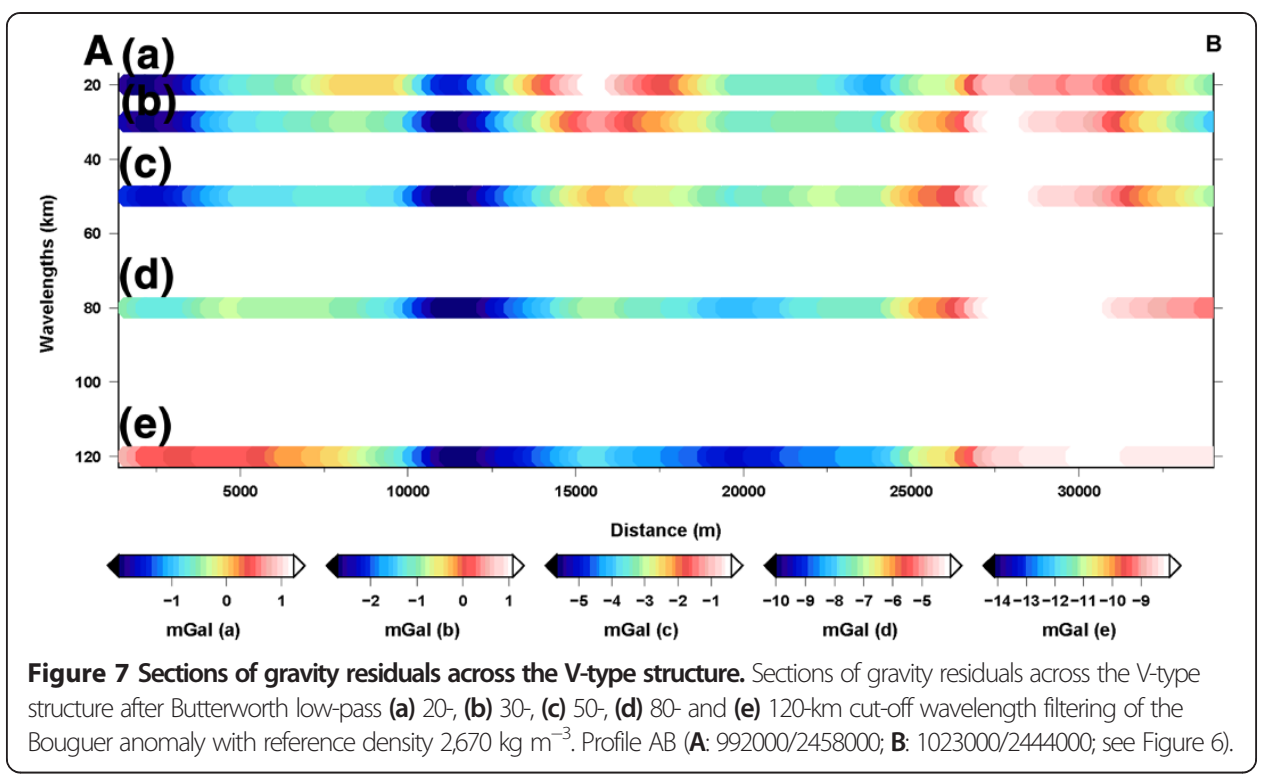

and gravity anomalies is observed (Figures 4 to 6) that favours the conclusion that the negative gravity anomalies probably do not just originate from simple lithology differences. Comparing the geometry of the sequential gravity residual anomalies to the fault zones of the 3D geological model based on 2D seismic profile observations (Dezayes et al. 2011), we may find similar V-type geometries. Earlier inversion results suggested a bulk density variation of about $250 \mathrm{~kg} \mathrm{~m}^{-3}$ (Schill et al. 2010). Interpreting this variation between bulk and matrix density in terms of fracture porosity along the seismically observed fault zones, we may suggest fracture porosity in the order of $10 \%$. This is in the range of natural fracture porosity observed in the reservoir zone in Soultz (Genter 1990; Géraud et al. 2010; Surma and Geraud 2003). It should be noted also that at the Soultz geothermal field, there is no major negative gravity anomaly observed at shallow depth.

Following the latter interpretation of the gravity pseudo-tomography in terms of enhanced fracture porosity indicated by negative anomalies combined with independent observations from temperature compilation, fluid chemistry and additional geophysical results, we propose an integrative conceptual model for the regional flow field for the geothermal fields in Northern Alsace (Figure 8). Regional infiltration at depth can occur from east to west (Pribnow and Schellschmidt 2000; Pribnow and Clauser 2000). Local meteoric water infiltration from west to east has been proposed earlier by the same authors. Following the distribution of negative anomalies with depth, it may occur along structures dipping at comparably shallow angle towards the east. Possible preferential pathways at shallow depth are indicated by AN1a and AN1b, which merge at intermediate depth. Up-flow may occur along relatively steep zones indicated by anomalies (AN2 and AN3) that behave in a relatively stable manner with changing low cut-off wavelength.

\section{Conclusion}

This study has shown that there is a strong link between structural features observed typically at the top of the crystalline basement and extrapolated to depth on the basis 


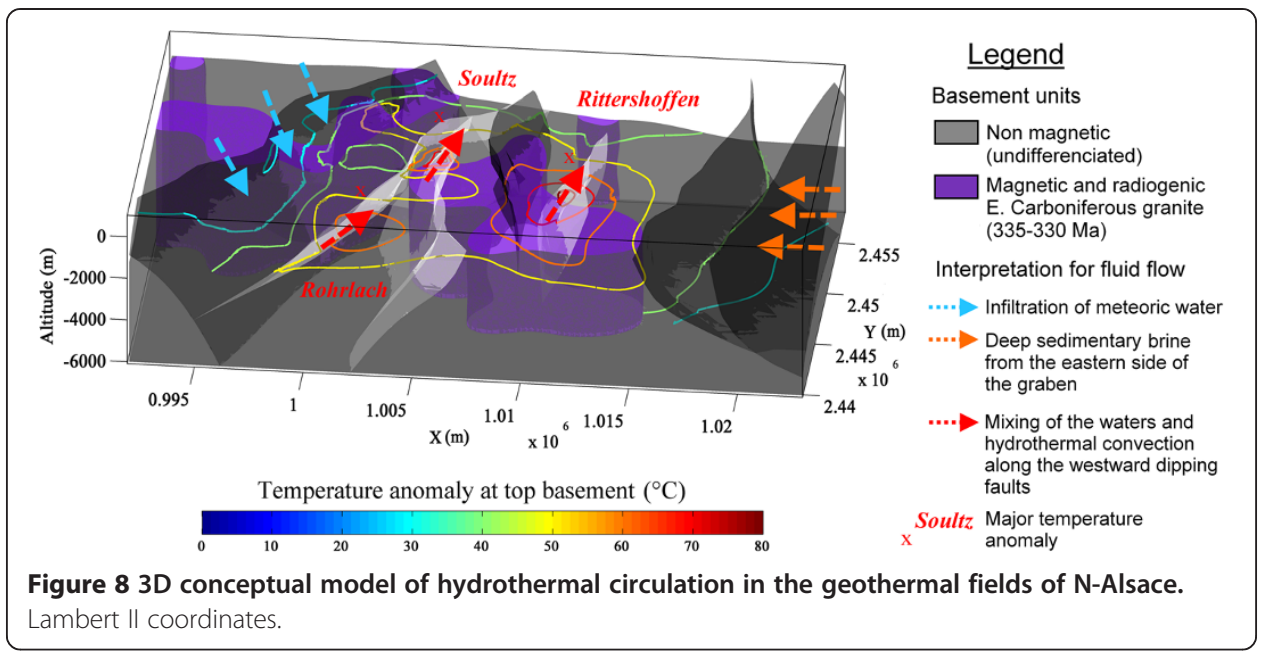

of the Soultz wells and the localisation of temperature anomalies east of W-dipping fault zone within horst structures. Furthermore, Butterworth filtering of Bouguer anomalies has revealed fault parallel negative anomalies in a pseudo-tomography. These anomalies show a relatively shallow eastward and steep westward dip in the west and east, respectively, and they join at a depth of about 6 to $8 \mathrm{~km}$ forming a V-shape structure.

Although gravity anomalies in the URG may originate from both lithological changes and fracture porosity, the interpretation of negative anomalies in terms of possible fluid pathways is supported by different independent methods such as fluid chemistry and magnetotellurics. Our comprehensive approach may be generally applied to visualise flow pathways in deep basins. The occurrence and asymmetric connection of faults in the basement is investigated more in details using mechanical and geodynamic modelling in a forthcoming paper.

\section{Abbreviations}

URG: Upper Rhine Graben; AN: anomaly; CTA: corrected temperature anomaly.

\section{Competing interests}

The authors declare that they have no competing interests.

\section{Authors' contribution}

PB carried out temperature interpolation as well as magnetic data treatment. He provided first interpretation and a draft of the manuscript. ES developed the scientific interpretation of the data and restructured and wrote a significant part of the manuscript. YA developed the software for Butterworth filtering and carried out the calculation of residual anomalies. CD supervised the 3D geological modelling and provided input for the geological description of the manuscript. All authors read and approved the final manuscript.

\section{Acknowledgements}

The authors would like to thank LIAG-Hannover, BRGM and EEIG Soultz and EOST Strasbourg for providing input data: borehole temperatures, seismic profiles and borehole geology for the creation of the 3D geological model, and geophysical data, respectively. J.-B. Edel (EOST) kindly provided the magnetic and gravity data; together with A. Genter (EEIG Soultz), we would like to thank them also for fruitful discussions. We would also like to thank B. Valley (ETHZ-UNINE) who provided necessary computing scripts, P. Renard (UNINE), P. Altwegg (UNINE) and L. Guglielmetti (UNINE) for their technical support and the three anonymous reviewers who helped improving the manuscript. This study was mainly conducted in the framework of the PhD of Paul Baillieux financed by Canton of Neuchâtel (Switzerland). The contribution of E. Schill and Y. Abdelfettah has been co-financed by the HGF Portfolio project 'Geoenergy' of the Helmholtz Association at KIT.

\section{Author details}

${ }^{1}$ Centre for Hydrogeology and Geothermics, Neuchâtel University, rue Emile Argand 11, Neuchâtel CH-2000, Switzerland. ${ }^{2}$ Institute for Nuclear Waste Disposal, Karlsruhe Institute of Technology, Hermann-von-Helmholtz-Platz 1, Karlsruhe 76128, Germany. ${ }^{3}$ BRGM, Geothermal Department, 3, avenue C.-Guillemin, 45060 Orléans cedex 2 36009BP, France. 
Received: 13 June 2014 Accepted: 13 November 2014

Published online: 19 December 2014

\section{References}

Abdelfettah Y, Schill E, Kuhn P (2014) Characterization of geothermally relevant structures at the top of crystalline basement in Switzerland by filters and gravity forward modelling. Geophys J Int 199(1):226-241

Agemar T, Schellschmidt R, Schulz R (2012) Subsurface temperature distribution in Germany. Geothermics 44:65-77

Altherr R, Holl A, Hegner E, Langer C, Kreuzer H (2000) High-potassium, calc-alkaline I-type plutonism in the European Variscides: northern Vosges (France) and northern Schwarzwald (Germany). Lithos 50(1-3):51-73

Aquilina L, Pauwels H, Genter A, Fouillac C (1997) Water-rock interaction processes in the Triassic sandstone and the granitic basement of the Rhine Graben: geochemical investigation of a geothermal reservoir. Geochimica Cosmochimica Acta 61(20):4281-4295

Bächler D, Kohl T, Rybach L (2003) Impact of graben-parallel faults on hydrothermal convection - Rhine Graben case study. Phys Chem Earth 28(9-11):431-441

Baillieux P, Schill E, Dezayes C (2011) 3D structural regional model of the EGS Soultz site (northern Upper Rhine Graben, France): insights and perspectives. Proceedings, Thirty-Sixth Workshop on Geothermal Reservoir Engineering, Stanford University, Stanford, California, SGP-TR-191

Baillieux P, Schill E, Moresi L, Abdelfettah Y, Dezayes C (2012) Investigation of natural permeability in graben systems: Soultz EGS site (France). Proceedings, Thirty-Seventh Workshop on Geothermal Reservoir Engineering, Stanford University, Stanford, California, January 30 - February 1, 2012 SGP-TR-194

Baillieux P, Schill E, Edel JB, Mauri G (2013) Localization of temperature anomalies in the Upper Rhine Graben: insights from geophysics and neotectonic activity. Int Geol Rev 55(14):1744-1762

Bartz, J., 1974. Die Mächtigkeit des Quartärs im Oberrheingraben. In: J.H. in Illies and K. Fuchs (Editors), Approaches to taphrogenesis Schweizerbart, Stuttgart, Germany, pages 78-87.

Beccaletto, L., Capar, L., Cruz-Mermy, D., Oliviero, G., Elsass, P., Perrin, A., Rupf, I., Nitsch, E. and Tesch, J., 2010. The GeORG project: seismic interpretation, structural pattern and 3-D modelling of the Upper Rhine Graben - first scientific results. Technical workshop. Geopotential of the Upper Rhine Graben (GeORG).(Novembre 18th 2010, Freiburg (Germany).).

Boutin R, Montigny R, Thuizat R (1995) Chronologie K-Ar et 39Ar-40Ar du métamorphisme et du magmatisme des Vosges, comparaison avec les massifs varisques avoisinants. Geologie De La France 1:3-25

Brun JP, Gutscher MA, DEKORP-ECORS teams (1992) Deep crustal structure of the Rhine Graben from seismic reflection data: a summary. Tectonophysics 208(1-3):139-147

Butterworth S (1930) On the theory of filter amplifiers. Wireless Eng 1:536-541

Campos-Enriquez JO, Hubral P, Wenzel F, Lueschen E, Meier L (1992) Gravity and magnetic constraints on deep and intermediate crustal structure and evolution models for the Rhine Graben. Tectonophysics 206(1-2):113-135

Cathelineau M, Boiron MC (2010) Downward penetration and mixing of sedimentary brines and dilute hot waters at 5 km depth in the granite basement at Soultz-sous-Forêts (Rhine Graben, France). C R Geosci 342(7-8):560-565

Clauser C, Villinger H (1990) Analysis of conductive and convective heat transfer in a sedimentary basin, demonstrated for the Rhine Graben. Geophys J Int 100(3):393-414

Cloetingh S, Cornu T, Ziegler PA, Beekman F (2006) Neotectonics and intraplate continental topography of the northern Alpine Foreland. Earth Sci Rev 74(3-4):127-196

Cornet F, Berard T, Bourouis S (2007) How close to failure is a granite rock mass at a $5 \mathrm{~km}$ depth? Int J Rock Mech Min Sci 44(1):47-66

Denlinger RP, Kovach RL (1981) Three-dimensional gravity modeling of the Geysers hydrothermal system and vicinity, northern California. Geologic Soc Am Bull 92:404-410

Dezayes C, Genter A, Valley B (2010) Structure of the low permeable naturally fractured geothermal reservoir at Soultz. C R Geosci 342(7-8):517-530

Dezayes, C., Beccaletto, L., Oliviero, G., Baillieux, P., Capar, L. and Schill, E., 2011. 3-D visualization of a fractured geothermal field: the example of the EGS Soultz site (Northern Upper Rhine Graben, France). Proceedings, Thirty-Seventh Workshop on Geothermal Reservoir Engineering Stanford University, Stanford, California, January 30 - February 1, 2012 SGP-TR-194

Dèzes P, Schmid SM, Ziegler PA (2004) Evolution of the European Cenozoic rift system: interaction of the Alpine and Pyrenean orogens with their foreland lithosphere. Tectonophysics 389:1-33

Dubois M, Ougougdal MA, Meere P, Royer JJ, Boiron MC, Cathelineau M (1996) Temperature of paleo- to modern self-sealing within a continental rift basin: the fluid inclusion data (Soultz-sous-Forêts, Rhine Graben, France). Ber Dtsch Mineral Ges 8(5):1065-1080

Dubois M, Ledesert B, Potdevin JL, Vancon S (2000) Determination of the formation conditions of carbonates in an alteration zone of the Soultz-sous-Forêts granite (Rhine Graben): the fluid inclusion record. C R Acad Sci II 331(4):303-309

Edel JB (2004) Structure et évolution du Fossé Rhénan, du Carbonifère à nos jours - apports de la géophysique. Bull Soc Hist Nat Ethnogr Colmar 65(2004):21-50

Edel JB, Weber K (1995) Cadomian terranes, wrench faulting and thrusting in central Europe variscides: geophysical and geological evidences. Geologische Rundschau 84:412-432

Edel JB, Campos-Enriquez O, Goupillot M, Kiro KN (1982) Levé magnetique au sol du Fossé rhénan supérieur. Interpretation géologique. Bull Bur Rech Géol Min 2:179-192

Edel JB, Montigny R, Royer JY, Thuizat R, Trolard F (1986) Paleomagnetic investigations and K-AR dating on the Variscan plutonic massif of the champ du feu and its volcanic-sedimentary environment, northern Vosges, France. Tectonophysics 122(1-2):165-185

Geiermann J, Schill E (2010) 2-D Magnetotellurics at the geothermal site at Soultz-sous-Forêts: resistivity distribution to about $3000 \mathrm{~m}$ depth. C R Geosci 342(7-8):587-599

Genter, A., 1990. Géothermie roches chaudes sèches: le granite de Soultz-sous-Forêts. (Bas-Rhin, France), Fracturation naturelle, altérations hydrothermales et interaction eau-roche. Université d'Orléans, France, PhD: 201. 
Géraud Y, Rosener M, Surma F, Place J, Le Garzic E, Diraison M (2010) Physical properties of fault zones within a granite body: example of the Soultz-sous-Forêts geothermal site. C R Geosci 342:566-574

Grecksch, G., Ortiz, A. and Schellschmidt, R., 2003. Thermophysical study of GPK2 and GPK3 granite Samples. HDR Project Soultz - Report. Leibniz Institute for Applied Geosciences, Hannover

Illies H (1965) Bauplan und baugeschichte des oberrheingrabens. Oberrheinische Geologische Abhandlungen 14:1-54

Illies HJ, Greiner G (1979) Holocene movements and state of stress in the Rhine Graben rift system. Tectonophysics 52(1-4):349-359

Illies JH, Baumann H, Hoffers B (1981) Stress pattern and strain release in the Alpine Foreland. Tectonophysics 71(1-4):157-172

Ishihara (1977) The magnetite-series and ilmenite-series granitic rocks. Min Geol 27:293-305

Just J, Kontny A, De Wall H, Hirt AM, Martin-Hernandez F (2004) Development of magnetic fabrics during hydrothermal alteration in the Soultz-sous-Forêts granite from the EPS1 borehole, Upper Rhine Graben. Geologic Soc London 238:509-526, Special Publications 01/2004

Klee G, Rummel F (1993) Hydrofrac stress data for the European HDR research project test site Soultz-sous-Forêts. Int J Rock Mech Min Sci Geomech Abstr 30:973-976

Kohl T, Bächler D, Rybach L (2000) Steps towards a comprehensive thermo-hydraulic analysis of the HDR test site Soultz-sous-Forêts. World Geothermal Congress 2000, Kyushu-Tohoku, Japan, pp 2671-2676, May-June 2000

Meller C, Kontny A, Kohl T (2014) Identification and characterization of hydrothermally altered zones in granite by combining synthetic clay content logs with magneto-mineralogical investigations of drilled rock cuttings. Geophys J Int 1999(1):465-479

Papillon E (1995) Traitements et interpretations des cartes d'anomalies magnétiques et gravimétriques du Fossé Rhénan supérieur. Dipl. Ing. Géophs, Strasbourg l, p 95

Pohanka V (1988) Optimum expression for computation of the gravity field of a homogeneous polyhedral body. Geophys Prospect 36:733-775

Pribnow DFC, Clauser C (2000) Heat and fluid flow at the Soultz hot dry rock system in the Rhine Graben. In: Iglesias E, Blackwell D, Hunt T, Lund J, Tamanyu S (eds) Proc. World Geothermal Conference 2000, Kyushu-Tohoku, Japan, pp. 3835-3840, CD-ROM (ISBN 0-473-06811-7). International Geothermal Association, Auckland New Zealand

Pribnow D, Schellschmidt R (2000) Thermal tracking of upper crustal fluid flow in the Rhine Graben. Geophys Res Lett 27(13):1957-1960

Rotstein Y, Edel JB, Gabriel G, Boulanger D, Schaming M, Munschy M (2006) Insight into the structure of the upper Rhine Graben and its basement from a new compilation of Bouguer gravity. Tectonophysics 425(1-4):55-70

Rummel F (1991) Physical properties of the rock in the granitic section of borehole GPK1, Soultz-sous-Forêts. Geotherm Sci Technol 3:199-216

Rummel, F. and König, E., 1991. Density, ultrasonic velocities and magnetic susceptibility measurements on the core material from borehole EPS1 at Soultz-sous-Forêts., Yellow report 8.(1991).

Sanjuan B, Pinault J-L, Rose P, Gérard A, Brach M, Braibant G, Crouzet C, Foucher J-C, Gautier A, Touzelet S (2006) Tracer testing of the geothermal heat exchanger at Soultz-sous-Forêts (France) between 2000 and 2005. Geothermics 35(5-6):622-653

Sanjuan B, Millot R, Dezayes C, Brach M (2010) Main characteristics of the deep geothermal brine $(5 \mathrm{~km})$ at Soultz-sous-Forêts (France) determined using geochemical and tracer test data. C R Geosci 342(7-8):546-559

Sausse J, Dezayes C, Dorbath L, Genter A, Place J (2010) 3D model of fracture zones at Soultz-sous-Forêts based on geological data, image logs, induced microseismicity and vertical seismic profiles. C R Geosci 342(7-8):531-545

Schill E, Kohl T, Baujard C, Wellmann J-F (2009) Geothermische Ressourcen in Rheinland-Pfalz: Bereiche Süd- und Vorderpfalz, Final report to the Ministry of Environment Rhineland-Palatine., p 55

Schill E, Geiermann J, Kümmritz J (2010) 2-D magnetotellurics and gravity at the geothermal site at Soultz-sous-Forêts. World Geothermal Congress 2010, Bali, Indonesia, 25-29 April 2010

Schumacher ME (2002) Upper Rhine Graben: role of preexisting structures during rift evolution. Tectonics 21(1)

Surma F, Geraud Y (2003) Porosity and thermal conductivity of the Soultz-sous-Forêts granite. Pure Appl Geophys 160(5-6):1125-1136

Valley B, Evans KF (2010) Stress heterogeneity in the granite of the Soultz EGS reservoir inferred from analysis of well bore failure. Proceedings World Geothermal Congress 2010, Bali, Indonesia, 25-29 April 2010

Ziegler PA (1992) European Cenozoic rift system. Tectonophysics 208(1-3):91-111

Ziegler PA, Schuhmacher ME, Dèzes P, Van Wees J-D, Cloething S (2004) Post-Variscan evolution of the lithosphere in the Rhine Graben area: constraints from subsidence modelling. Geologic Soc London 223(1):289-317, Special Publications

doi:10.1186/s40517-014-0016-y

Cite this article as: Baillieux et al:: Possible natural fluid pathways from gravity pseudo-tomography in the geothermal fields of Northern Alsace (Upper Rhine Graben). Geothermal Energy 2014 2:16. 